\title{
A FIGURA DE BADEN-POWELL NO CENÁRIO EDUCACIONAL DO SÉCULO XX: UM NOVO OLHAR SOBRE SUA HISTÓRIA DE VIDA
}

\author{
Ricardo Rocha Rabelo ${ }^{1}$ \\ Universidade Tiradentes (UNIT) \\ rocharabelo@yahoo.com.br \\ Raylane Andreza Dias Navarro Barreto ${ }^{2}$ \\ Universidade Tiradentes (UNIT) \\ raylane_navarro@unit.br
}

\section{RESUMO}

Baden-Powell nasceu na Inglaterra no dia 22 de fevereiro do ano de 1857. Em 1907 funda o Escotismo, a partir de uma experiência em forma de acampamento envolvendo vinte jovens ingleses, na ilha de Brownsea, o qual torna-se uma das práticas educativas mais disseminadas no mundo ao longo do século XX. Este artigo tem como objeto de estudo a história de vida de Baden-Powell, detacando sua atuação militar, como escritor e como fundador do Escotismo. O objetivo é sua história de vida a partir de um outro olhar, a partir das categorias propostas por Sirinelli - a de intelectual - e da concepção de John Locke a de gentleman. Pudemos constatar que ele foi um intelectual e um gentleman, o que o torna uma figura importante do século XX. A pesquisa é do tipo bibliográfica e seu trato é qualitativo. As fontes utilizadas são obras do próprio Baden-Powell, de militantes do Movimento Escoteiro e de pesquisadores da temática.

Palavras-chave: Baden-Powell; Gentleman; Intelectual.

\section{FIGURE OF BADEN-POWELL OF EDUCATIONAL SCENARIO IN THE TWENTIETH CENTURY: A NEW LOOK AT YOUR LIFE STORY}

\begin{abstract}
Baden-Powell was born in England on 22 February in the year 1857. In 1907 he founded Scouting, from a camp experience shaped involving twenty young Englishmen, on Brownsea Island, which becomes an educational practices more widespread in the world throughout the twentieth century. This article has as object of study the life history of Baden-Powell, its action detacando military, as a writer and founder of Scouting. The goal is his life story from another perspective, from the categories proposed by Sirinelli - the intellectual - and the conception of John Locke - that of a gentleman. We found that he was an intellectual and a gentleman, which makes it an important figure of the twentieth century. The research is the type of literature and their treatment is qualitative. The sources used are the work of Baden-Powell himself, militants of the Movement and researchers of the theme.
\end{abstract}

Keywords: Baden-Powell; Gentleman; Intelectual.

\section{Introdução}

Baden-Powell, ou B-P, como ficou conhecido mundialmente, nasceu na Inglaterra no dia 22 de fevereiro do ano de 1857. Ainda na infância viveu experiências junto à natureza muito marcantes ao lado de seus irmãos mais velhos, onde, através de excursões, aprendeu a acampar, a cozinhar, a manobrar um barco, dentre outras destrezas. Na escola 
foi tido como um aluno abaixo da média, mas destacava-se por suas habilidades manuais no desenho e na pintura, no canto e nas artes cênicas. Terminou os estudos secundários e ingressou no exército, onde trilhou uma carreira destacada, principalmente pelo episódio da cidade africana de Mafeking, onde ocorreu um cerco militar, de 217 dias, em que ele foi designado para estar no comando e o fez com êxito e perspicácia, visto sua tropa ser três vezes inferior numericamente.

Baden-Powell tornou-se o General mais jovem da história da Inglaterra e utilizando-se de sua experiência militar escreveu Aids to Scouting, livro com ensinamentos sobre como acampar e como utilizar técnicas de sobrevivência em regiões selvagens, dirigido a exploradores militares. $\mathrm{O}$ sucesso desta obra foi grande e por isso resolveu reescrevê-lo com o foco voltado aos jovens. A partir daí, Baden-Powell, escreve dezenas de livros, centenas de artigos e esboça o que mais tarde se tornaria uma das práticas pedagógicas mais disseminadas no mundo: o Escotismo. Morreu no Quênia, África, em oito de janeiro de 1941, ao lado de sua esposa, Olava Powell.

Este artigo tem como objeto de estudo a história de vida de Baden-Powell, militar, escritor e fundador do Escotismo. O objetivo é evidenciar elementos de sua trajetória que o caracterizam (ou não) como um intelectual, a partir da noção de intelectual proposta por Sirinelli (1996), segundo a qual pode se configurar em dois entendimentos, a saber: um amplo e sociocultural, onde se encaixariam aí os criadores e os mediadores culturais, e um entendimento mais restrito, que se baseia na noção de engajamento. Ou caracterizá-lo apenas como um Gentleman, na concepção de John Locke. A pesquisa é do tipo bibliográfica e se apóia nas obras do próprio Baden-Powell, de militantes do Movimento Escoteiro e de pesquisadores da temática.

\section{Baden-Powell e sua infância: prelúdios de uma vida ativa}

Filho do Pastor protestante e professor Baden Powell ${ }^{3}$ e de Henrietta Grace Powell, Robert Stephenson Smyth Powell nasceu no dia 22 de fevereiro do ano de 1857, em Londres, Inglaterra, cuja população era em torno de vinte milhões de habitantes. Teve doze irmãos, dos quais quatro faleceram prematuramente, ainda na infância. Todos foram bem sucedidos em suas profissões: escritor, atleta, militar, musicista, policial e pintor. Após a morte de seu pai, sua mãe, Henrietta Powell, tomou a decisão de transformar o nome Baden em sobrenome de modo que os membros da família assinariam a partir de então o sobrenome Baden-Powell, fato legalizado no dia 21 de dezembro de 1869.

Nasceu em uma época em que se começava a trabalhar muito cedo, na infância, e os adultos tinham cargas horárias que chegavam a dezesseis horas por dia, em troca de baixíssimos salários. A educação para todos não havia se materializado e somente os filhos de famílias abastadas eram instruídos, nas escolas particulares ou por meio de preceptores, isto é, professores individuais que ofereciam seus serviços nas próprias residências destas famílias, o que não foi o caso de Baden-Powell. Sua mãe, entretanto, conseguiu, a partir dos relacionamentos deixados por seu pai, bolsa para estudar na Escola de Chartehouse, uma instituição com mais de duzentos anos de tradição na Inglaterra. Embora tenha entrado tardiamente na escola, aos onze anos, já sabia ler e escrever além de desenhar e pintar, mas ainda assim foi considerado um aluno abaixo da média. Sobre esta situação, esclareceu o diretor da escola ao pai do menino:

[...] a capacidade de seu filho é maior que a demonstrada nos resultados acadêmicos do período escolar. Eu estou satisfeito com a sua conduta e espero que ele trabalhe o suficiente para preparar-se para a vida após o seu desligamento da escola quando atingir a idade...(BOULANGER, 2000, p. 19) 
Em contrapartida se destacava por suas habilidades manuais no desenho e na pintura, no canto e nas artes cênicas. Por isso, participou ativamente do coral, da orquestra e da banda da escola. Nos esportes, destacava-se como goleiro, função que gostava de jogar no futebol. Já no teatro amador, atividade que o diretor da escola incentivava bastante por ver nesta um meio de educação, Baden-Powell a levava muito a sério, aproveitando para exibir seu lado cômico. Mas, dedicava mesmo boa parte de seu tempo escolar à equipe de tiro com rifle, cuja prática constante o revelou exímio atirador. Este perfil revela a sobrepujança do pragmatismo jovial do rapaz sobre as disciplinas teóricas.

Segundo Boulanger (2000), a mudança da Escola do meio urbano para o interior fez com que Baden-Powell escapasse inúmeras vezes da aula para explorar os bosques que haviam nas proximidades do novo prédio escolar. Observava atentamente os tipos de animais que ali viviam e procurava ter experiências sozinho, como por exemplo, preparar alimentos em fogueira sem fumaça, tendo em vista não ser denunciado. O jovem BadenPowell já parecia saber que a aprendizagem (grifo meu) estava muito além do conhecimento livresco frisado por Comenius, ao dizer este que:

Em conclusão, é preciso ensinar aos homens que, na medida do possível, o saber não deve ser procurado nos livros, mas no céu, na terra, nos carvalhos, nas faias, ou seja, é preciso conhecer e observar as coisas em si, e não só as observações e o testemunho de outras pessoas sobre elas". (COMENIUS, 2002, p. 192).

Tais aventuras eram de conhecimento do diretor da escola, que não o advertia, por crer que favoreceriam a auto-educação de Baden-Powell. No período das férias, unia-se aos três irmãos mais velhos em aventuras como caminhadas por vales, montanhas e florestas, explorando ao máximo o que a vida ao ar livre oferecia. As aventuras em riachos com canoas e no mar, com jangadas e barcos, também foram uma constante do quarteto, que chegava a passar dias em alto mar, navegando e pescando. Chegaram a construir duas embarcações, uma de cinco e outra de dez toneladas. Nestas experiências Baden-Powell aprendeu a navegar, a conservar o barco, a cozinhar e a nadar.

\section{Baden-Powell e a vida militar}

Ao terminar os estudos secundários o jovem foi convidado a prestar exames em Oxford, mas não foi bem sucedido. Fez exames também para Universidade de Christ Church onde, igualmente, não obteve êxito. O pai de Baden-Powell fez brilhante carreira de professor na Universidade de Oxford e certamente teria comungado da consternação da família com as reprovações do filho, o qual gostaria de se tornar ator ou artista, desejo que a família não via com bons olhos para se ter como profissão.

Ao saber, fortuitamente, de um concurso para oficial do exército inglês, resolveu submeter-se aos exames e galgou sucesso nas duas opções que fizera: Infantaria, ficando em quinto lugar dentre os setecentos e dezoito examinados, e Cavalaria, onde foi aprovado em segundo lugar. Embora Baden-Powell não pensasse na carreira militar como profissão até então, o mérito da aprovação no referido concurso deixou a sua família muito orgulhosa, principalmente sua mãe, cujo avô havia sido almirante e um tio, que foi coronel do exército. Henrietta Powell fez questão de escrever para as instituições de Oxford e Christ Church contando da aprovação do filho. Ambas manifestaram alegria pelo êxito do jovem e lamentaram por não tê-lo entre seus alunos, como relata o Deão de Christ Church, Dr. Lidell, referindo-se à mãe de Baden-Powell: 
Eu asseguro a você que não foi por minha vontade que o seu filho não foi aceito em Christ Church. O examinador de matemática, por quem todos os candidatos devem passar, achava necessário examiná-lo em assuntos simples e o seu relatório sobre as respostas do seu filho foi tal que tornouse impossível para mim aceitá-lo... Eu lamento e expresso sinceramente meu pesar de não ter o nome dele nos registros da nossa Casa. Eu creio que devem pensar da mesma forma em Oxford.

Baden-Powell optou por pertencer a Cavalaria e foi direcionado para o $13^{\circ}$ Regimento de Hussardos, então aquartelado na Índia, para onde o jovem Subtenente seguiu em 30 de outubro de 1876, a bordo do navio Serápis no porto de Portsmouth. Seguiu para Lucknow, no norte da Índia, onde aguardava o seu regimento militar. Apesar de não ter experiência de treinamento militar, saiu-se bem perante seus subordinados, que o viram como um oficial inteligente e muito bem humorado.

Enquanto militar, Baden-Powell teve a oportunidade de viajar muito, especialmente para o continente africano, o que lhe permitiu conviver com tribos de guerreiros, e para a América do Norte, interagindo com índios e vaqueiros. Agregou bastante experiência com a exploração geográfica destas regiões e o contato com os aborígenes. Por destacar-se bem nestas missões e galgar êxito nos exames para postos superiores, chegou ao posto de Capitão com apenas vinte e seis anos de idade e foi promovido a Major-General após confronto militar onde comandou com êxito e perspicácia sua tropa, que contava com um efetivo de 1215 homens enquanto que as tropas inimigas (os bôeres ${ }^{4}$ ) contavam com um quantitativo de 9000 integrantes. Após sofrer um cerco de 217 dias, conseguiu resistir às várias investidas dos bôeres. Para isso montou estrategicamente seis pequenos fortes em forma de círculo que foram suficientes na resistência até a chegada do reforço de tropas inglesas. Conseguiu auxilio de jovens civis para funções básicas de primeiros socorros, cozinha e comunicação. Este fato ficou conhecido como o episódio de Mafeking e é considerado o maior feito da carreira militar de Baden-Powell. Com tal desempenho, ele sagrou-se herói e tornou-se o General mais jovem da historia da Inglaterra, em 1900, aos 43 anos de idade. Seis anos mais tarde:

Ao retornar ao seu país, em 1906, depois de 30 anos em viagens cumprindo missões militares, Baden-Powell considerou desalentador o quadro social do seu país. A Inglaterra que ele conhecia era um país conservador, moldado a partir dos hábitos difundidos pela rainha Vitória, com princípios rígidos que vigoraram no momento em que a economia inglesa se transformara de agrícola na mais industrializada do mundo. A elite britânica se considerava guardiã da democracia, das tradições da Igreja e do Estado. (NASCIMENTO, 2008, p. 33).

A partir de então, Baden-Powell começava a pensar em afastar-se do exército e dedicar-se a um projeto que vislumbrava já há tempos: o Escotismo. Ao submeter o pedido de reforma (afastamento) ao amigo e Secretário da Guerra do Exército, Haldane, recebeu a seguinte resposta: "Eu sinto", escreveu ele, "que a sua organização terá tanta importância no futuro que provavelmente o maior serviço que você pode prestar ao seu país é dedicarse a ela" (BOULANGER, 2000, p. 136).

\section{Baden Powell e o seu legado: o escotismo}

Em 1904 Baden-Powell, visitando a Escócia, teve a oportunidade de inspecionar uma das maiores organizações juvenis da época: os Boys Brigade ${ }^{5}$. Observou o entusiasmo dos 
jovens ao desfilarem e dos adultos prestigiando de forma igualmente entusiasmada as performances dos rapazes. Baden-Powell percebeu que esses jovens adeririam a qualquer tipo de treinamento se este fosse interessante para eles. Quanto aos adultos, viu que se sacrificariam em prol do treinamento desses garotos. Não concordando com as características militares conferidas aos Boys Brigade, Baden-Powell parabenizou o comandante da organização juvenil, porem, sugeriu que se houvessem atividades mais variadas e atrativas o número de integrantes poderia ser bem maior. A crítica foi bem aceita e como contra-argumento, Baden-Powell foi desafiado a incrementar suas sugestões num movimento juvenil próprio, que tivesse uma visão de mundo (grifo meu) diferente, ou seja, que tivesse um "[...] Conjunto de aspirações, de sentimentos e de idéias que reúne os membros de um mesmo grupo (de uma classe social, na maioria das vezes) e os opõe aos outros grupos". (GOLDMANN, 1955, apud CHARTIER, 1990, p. 47). Neste caso, a oposição era aos Boys Brigade e todos os outros tipos de associações ou agremiações juvenis cujas características assemelhavam-se aos moldes e ritos militares.

Muito entusiasmado, no ano de 1907 Baden-Powell realizou uma experiência com vinte rapazes com idades entre doze e dezesseis anos, na Ilha britânica de Brownsea ${ }^{6}$. Utilizou-se de um conjunto de experiências sobre técnicas de sobrevivência e de exploração no meio silvestre, adquiridas nas suas aventuras com os irmãos mais velhos e também no exército. O episódio, que ocorreu na forma de acampamento, durou uma semana e os jovens tiveram noções de primeiros socorros, observação periférica, técnicas de segurança na floresta e na cidade. A pretensão de Baden-Powell com este acampamento era

Oferecer aos jovens a oportunidade de um aprendizado dinâmico e participativo, fora dos moldes engessadores da educação britânica do início do século XX, para retirá-los da ociosidade das ruas de Londres sem, no entanto, pretender substituir o papel da educação formal, mas antes, completá-lo dando ênfase no aprendizado junto à natureza, longe dos prédios e muros da cidade. (PEREIRA, 2004, p. 10).

Nascia aí uma das práticas educativas mais disseminadas no mundo no século XX: o Escotismo. O Movimento Escoteiro foi marcado pelo Pragmatismo norte-americano e pelas pedagogias ativas do final do século XIX, dentre as quais pode-se citar a idealizada por Maria Montessori, cuja base do seu método balisava-se pelo caráter experimental da natureza da criança, enfatizando as atividades sensorio-motoras, desenvolvidas por intermédio de exercícios da vida prática. Além dos aspectos físicos e cognitivos, BadenPowell preocupou-se também em desenvolver nos jovens princípios que sedimentasse a formação do caráter. Podemos identificar em seu método, também, fundamentos da pedagogia de Rousseau (2004), onde este via a imaginação (grifo meu) como a mais ativa das faculdades virtuais. No Escotismo, a imaginação é aguçada em diferentes tipos de atividades: na dramaturgia, nas atividades de campo ou nas ações da vida cotidiana. A Educação Natural em que se baseava Rousseau, onde se procura tornar um homem próprio para todas as condições humanas, é identificada no método escoteiro uma vez que as bases desenvolvidas por meio das atividades devem ser levadas para todas as circunstancias e tempos da vida. Desta forma, tratava-se o Escotismo de uma

[...] Pedagogia organizada durante a primeira década do século $\mathrm{XX}$, falando em ensinar disciplina aos jovens, fixar valores, desenvolver habilidades e difundir saberes, conforme alguns padrões recorrentes às 
práticas da Pedagogia Moderna naquele período [...]. (NASCIMENTO, 2005, p. 252).

A experiência de Brownsea deu certo ${ }^{7}$ e a partir dela Baden-Powell resolveu escrever um livro, Scouting for Boys ou Escotismo para Rapazes, inicialmente vendido nas bancas de jornais inglesas, em fascículos (foram seis ao todo). O livro também foi sucesso de vendas e teve influência direta na disseminação do Escotismo por toda a Inglaterra. $\mathrm{O}$ êxito do livro e as sucessivas palestras e conferências proferidas por Baden-Powell fizeram com que em pouco mais de três anos esta prática pedagógica já estivesse presente em vários países do mundo. Para Baden-Powell

Escotismo é um jogo para jovens, dirigido por eles mesmos, no qual irmãos mais velhos proporcionam aos mais moços um ambiente sadio e os encorajam à prática das atividades também sadias que auxiliem o desenvolvimento do espírito de cidadania. [...] Sua maior atração reside no contato e estudo da natureza, a vida ao ar livre, os trabalhos manuais em madeira, rústicos e toscos. Ele atua diretamente sobre o individuo e não sobre o conjunto. [...] Ele cultiva e eleva tanto o intelecto, como as qualidades puramente físicas e morais. (POWELL, 2000, p. 26).

Inicialmente as pretensões do movimento escoteiro visavam instruções que levassem à auto-educação dos jovens ingleses. Baden-Powell constatou que muitos jovens ingleses estavam entregues aos vícios do fumo, do álcool, da libertinagem. Acerca desta constatação sugeriu, em sua obra Caminho para o Sucesso:

Em vez de vagabundear sem objetivo e das conversas pornográficas da esquina você encontrará muito o que fazer sob a forma de excursões, acampamentos e outros divertimentos varonis ao ar livre e uma espécie de clube limpo para frequientar durante a semana - a sede dos Pioneiros. (POWELL, 1984, p. 127)

Porém, o que ele, Baden Powell, não sabia, ao propor um método para a realidade inglesa da época, era ter aberto uma espécie da caixa de pandora do Escotismo, ou seja, o sucesso do movimento foi tamanho que extrapolou as circunscrições geográficas de seu país, disseminando-se mundo afora. Nem o mais otimista dos pensamentos de BadenPowell poderia imaginar tais desdobramentos. (BOULANGER, 2000).

Os princípios do Movimento Escoteiro materializam-se por meio de atividades práticas que se caracterizam pelo aprender fazendo, comumente realizados ao ar livre, na vida mateira (no campo). A idéia era conduzir o jovem a descobrir o prazer da autoeducação e do autodesenvolvimento. A finalidade do Movimento Escoteiro, assim, era menos a de encorajar a aquisição de conhecimentos e mais a de estimular a capacidade e o desejo de adquiri-los. Esta aprendizagem não formal:

[...] permite viver experiências pessoais que interiorizam e consolidam o conhecimento, as atitudes e as habilidades. Desta maneira, e do ponto de vista cognitivo, se substitui a simples recepção de informação pela efetiva aquisição de conhecimento; no domínio da afetividade, se substitui a norma imposta pela norma descoberta e a disciplina exterior pela interior; e, no campo motriz, a passividade receptiva do destinatário cede lugar à criatividade efetiva do realizador. (THOMÉ, 2006, p. 167) 
Este tipo de educação que fundamenta o Escotismo traz em seu bojo as principais características do movimento de renovação pedagógica escolar que ganhou ênfase na segunda metade do século XIX, na Europa e nos Estados Unidos, as quais buscaram em Pestallozi, Montessori, Decroly e Dewey, principalmente, as bases conceituais para seu desenvolvimento. No Brasil, este movimento renovador iniciou-se no fim do século XIX e ganhou maior publicidade nas décadas iniciais do século XX com aquele que ficou conhecido por Movimento Escolanovista, onde a atividade educativa partiria do concreto para o abstrato, do simples para o composto, do conhecido para o desconhecido, isto é, o processo pedagógico se daria a partir de um contato prolongado com a realidade e seus dados empíricos. (CAMBI, 1999).

Após constatar o sucesso do Movimento Escoteiro para além das fronteiras inglesas, Baden-Powell fez questão de difundir pessoalmente o seu método em vários países do mundo. Assim:

Em toda a parte, em África, na Índia, na Inglaterra, ele descobriu o que há de extraordinariamente semelhante em todas as crianças do mundo: o que há de universal no homem, a natureza humana, idéia condutora, como diria Claude Bernard, segundo a qual os indivíduos constroem a si próprios. Para Baden-Powell, que não fez filosofia, a natureza é uma realidade experimental. Daqui resulta para ele, um humanismo mais profundo que as diferenças de raça ou de classe. (NASCIMENTO, 2008, p. 43).

Ao final da segunda década do século XX já era ele um consagrado conferencista internacional, muito requisitado para divulgar o Movimento que fundou, bem como narrar suas experiências na vida militar. Esta fase contribui bastante para que Baden-Powell tivesse reconhecimento de várias entidades, instituições e recebesse inúmeros títulos e condecorações.

\section{Baden-Powell: produção literária, condecorações e títulos.}

Ao longo de sua história de vida Baden-Powell recebeu diversos títulos honoríficos e várias condecorações, bem como foi autor de uma produção literária razoavelmente considerável. A maior parte de suas obras foi dedicada ao Escotismo. Escreveu 35 livros, 21 livretos ou panfletos, mais de 1500 artigos para o "The Scout" e inúmeros artigos e desenhos para jornais ingleses. Scouting for Boys ou Escotismo para Rapazes é o livro mais conhecido de sua produção. Estimativas levantadas no ano de 2010 revelam que o número de exemplares vendidos supera os 150 milhões de unidades. Segundo Robleño (2011) estes números credenciam a obra como um Best seller, sendo considerado o livro mais vendido da história, atrás apenas da Bíblia, do Alcorão e do Livro Vermelho. Quanto às condecorações e títulos honoríficos, são conhecidos os seguintes, por ordem cronológica $^{8}$ :

Condecorações:

1901 - Companheiro da Ordem do Banho (CB); 1909 - Cavaleiro da Ordem Vitoriana (KCVO); 1910 - Ordem do Mérito do Chile; 1912 - Cavaleiro da Ordem do Banho (KCB); 1919- Cavaleiro da Grande Cruz de Alfonso XII (Espanha); 1920 - Grande Comandante da Ordem de Cristo (Portugal) / Grande Comandante da Ordem do Redentor (Grécia); 1921 - Storklos da Ordem de Danneborg (Dinamarca) / Comandante da Ordem da Cruz da Bélgica; 1922 - Comandante da Legião de Honra (França); 1923 - Grande Cruz da Ordem Vitoriana / Baronete; 1927 - Ordem da Polônia Restitua; 1928 - Cavaleiro da Grande Cruz da Ordem de São Miguel e São Jorge (Inglaterra) / Ordem da Amanulla 
(Afeganistão); 1929 - Primeira Classe da Ordem do Mérito (Hungria) / Ordem do Leão Branco (Tchecoslováquia); Ordem da Phoenix (Grécia) / Barão Baden-Powell of Gilwell; 1931 - Grande Cruz da Ordem do Mérito (Áustria); 1932 - Grande Cruz de Gediminus (Lituânia) / Grande Cruz de Orange de Nassau (Holanda); 1933 - Comandante da Ordem do Carvalho de Luxemburgo / Cruz Vermelha da Estônia / Grande Cruz da Ordem da Espada (Suécia); 1936 - Grande Cruz da Legião de Honra (França); 1937 - Premio Wateler da Paz / Ordem do Mérito da Inglaterra.

Títulos Honoríficos:

1910 - Legum Doctor - Universidade de Edimburgo (Escócia); 1923 - Legum Doctor - Universidade de Toronto (Canadá) / Legum Doctor - Univesidade McGill (Montreal, Canadá) / Doctor of Civil Law - Universidade de Oxford (Inglaterra); 1929 Legum Doctor - Universidade de Liverpool (Inglaterra); 1931 - Legum Doctor Universidade de Cambridge (Inglaterra).

No ano de 1939 Baden-Powell é indicado para o Prêmio Nobel da Paz. Todos estes títulos, condecorações e produção literária que traçam a história de vida de Baden-Powell nos leva a refletir sobre a possibilidade de considerá-lo um intelectual, um gentleman ou mesmo ambos, na história do século XX. O fato de ter sido considerado um aluno "mediano" na escola, no que diz respeito aos conteúdos de disciplinas clássicas, não foi impeditivo para que se tornasse escritor de uma produção razoável (quantitativamente) e importante (qualitativamente). Tal fato talvez reforce a idéia da importância da autoeducação, principalmente através dos sentidos, muito vivenciada por Baden-Powell, em todas as fases de sua vida, que o levou a ser um explorador de si mesmo e conhecedor outras culturas, graças também, a sua profissão como militar. Esta combinação muito possivelmente alargou o conjunto de conhecimentos ou utensilagens mentais, como nos diz Roger Chartier, que tinha Baden-Powell, e contribuiu para se tornasse escritor e conquistasse os títulos já mencionados.

\section{Baden-Powell: intelectual, gentleman ou ambos?}

Robert Stephenson Smith Baden-Powell foi um personagem que não passou despercebido pelo século XX. Sua destacada carreira militar, os títulos que recebeu, sua considerável produção literária e, sobretudo o legado que deixou no campo da Educação ao implantar o Escotismo são evidências que podem comprovar tal assertiva. No entanto, como nos diz o historiador Jacques Le Goff, ao se referir sobre o interesse da memória coletiva e da história, ressalta que este já não se cristaliza exclusivamente sobre os grandes homens, os grandes acontecimentos, os grandes heróis.

Assim, partiu-se da seguinte questão: foi Baden-Powell um intelectual? A sua história de vida o credencia como tal? Ou foi ele, na concepção do filósofo John Locke, apenas um verdadeiro Gentleman? Antes de tentarmos responder a estas perguntas faz-se necessário primeiro esclarecer o que é ser um intelectual? Quais critérios são utilizados para se definir alguém como intelectual?

De acordo com o pesquisador francês Jean François Sirinelli, o termo intelectual tem sido frequentemente destacado pelo seu caráter polissêmico, que tem evoluído no tempo concomitante às mutações sociais, em especial da França, contexto de análise deste pesquisador. Por isto defende uma definição de intelectual que seja variável, porem baseada em invariantes, as quais, podem se configurar em dois entendimentos, a saber: um amplo e sociocultural, onde se encaixariam aí os criadores e os mediadores culturais, e um entendimento mais restrito, que baseia-se na noção de engajamento. Com o intuito de esclarecer ambas as acepções, o autor especifica: 
No primeiro caso, estão abrangidos tanto o jornalista como o escritor, o professor secundário como o erudito. Nos degraus que levam a esse primeiro conjunto postam-se uma parte dos estudantes, criadores ou "mediadores" em potencial, e ainda outras categorias de "receptores" da cultura. (SIRINELLI, 1996, p. 242)

Estabelecendo como parâmetro que Baden-Powell foi um professor (da educação extra-escolar é verdade, o que não o descredencia da função) e um escritor, pode-se inferir que ele se configura como um intelectual dentro de um modelo maior, o amplo e sociocultural. Ao o analisarmos sob o parâmetro mais restrito, do engajamento, BadenPowell também pode ser caracterizado um intelectual, tomando como referência o engajamento ou a causa que defendeu e se empenhou por mais da metade de sua vida, que foi o Escotismo, uma prática educativa que se disseminou mundo afora após o engajamento de Baden-Powell em fundá-lo na Inglaterra. Verifica-se assim que ele enquadra-se dentre os intelectuais "[...] que tiveram importância enquanto viveram". (SIRINELLI, 1996, p. 246).

No tocante a Baden-Powell ser considerado um Gentleman, tomemos como parâmetro comparativo a educação que recebeu e as ações que desenvolveu ao longo de sua vida. A formação de um Gentleman, segundo John Locke, está fundamentada numa concepção integral que contempla a Educação física, moral e intelectual do indivíduo. Sobre essa formação integral comenta o próprio Locke:

A felicidade e a desgraça do homem são, em grande parte, sua própria obra. Aquele que não dirige seu espírito sabiamente, não tomará nunca o caminho certo, e aquele que cujo corpo seja doente e débil, nunca poderá avançar por ele. Reconheço que alguns homens têm uma constituição corporal e espiritual tão vigorosa e tão bem modelada pela natureza, que apenas necessitam do auxilio dos demais. (LOCKE, 1986, p. 31).

A assertiva de John Locke tem estreita ligação com a formação de Baden-Powell, que teve experiências corporais e formativas bastante ativas enquanto estudante, militar e escotista. Quanto à formação intelectual, pode-se dizer que foi produtiva, se tomarmos como parâmetro a sua produção literária (quantitativa e qualitativamente). Dentre ela destaca-se Scouting for Boys, um dos livros mais vendidos no mundo em todo século XX. No tocante à educação moral, os valores que recebeu em família e na escola foram motivadores para que os compartilhasse com os jovens ingleses, inicialmente, e mais tarde, aos jovens de todo o mundo, por meio de seus exemplos e também de seus livros. Em um deles, Caminho para o Sucesso, Baden-Powell procura tratar de explanar sobre os valores que formam o caráter, bem como os vícios que o deformam. Sobre este livro, ele faz questão de enfatizar que: "[...] não é para ser lido por homens experimentados. É para vocês, jovens, que o escrevo; vocês que tem o bom senso de olhar para frente, ansiosos por ver para onde vão e o que irão fazer na vida”. (POWELL, 1984, p. 15).

Portanto, ao analisar a história de vida no decorrer de seus 84 anos, verifica-se que Baden-Powell foi um gentleman, segundo a concepção que John Locke confere ao termo.

\section{Considerações finais}

Nascido em 22 de fevereiro de 1857 na Inglaterra, Robert Stephenson Smith Baden-Powell, ou B-P, como ficou conhecido mundialmente, foi educado na escola 
pública de Charterouse, uma instituição com mais de duzentos anos de tradição na Inglaterra. Classificado como um aluno mediano no que diz respeito aos estudos escolares, sobressaiu-se em atividades mais pragmáticas como o canto, o teatro e o tiro ao florestais . Ao lado de seus irmãos mais velhos teve experiências sensoriais as mais diversas, especialmente aquelas realizadas ao ar livre, em acampamentos, explorações na mata e em embarcações marítimas. Fez uso destas experiências no exército, onde ingressou aos dezenove anos e trilhou uma carreira de destaque onde foi considerado o general mais jovem da história da Inglaterra.

Em 1907 funda o Escotismo, a partir de uma experiência em forma de acampamento envolvendo vinte jovens ingleses, na ilha de Brownsea. O Escotismo tornase uma das práticas educativas mais disseminadas no mundo ao longo do século $\mathrm{XX}$. Dedicou-se integralmente ao Movimento Escoteiro da metade de sua vida até a sua morte, em oito de janeiro de 1941, no Quênia, África.

As indagações levantadas neste estudo tiveram pretensões diferentes das pesquisas que já foram realizadas sobre Baden-Powell, que geralmente o associam quase que exclusivamente ao Movimento Escoteiro, por ter sido seu fundador. $\mathrm{O}$ foco deste estudo teve por referência a história de vida de Baden-Powell e a partir dela, identificá-lo (ou não) como um intelectual, segundo parâmetro comparativo apoiado nos estudos de Sirinelli (1996) ou identificá-lo como um gentleman, segundo a concepção apontada por John Locke.

Ao analisar a trajetória de Baden-Powell a partir dos parâmetros supracitados, levando em conta a sua formação escolar, os títulos que recebeu em vida pelas ações que desenvolveu no exército e no Escotismo e a sua produção literária, podemos considerar que ele foi um intelectual e um gentleman no cenário do século $\mathrm{XX}$, uma vez que, tomando como referência o engajamento ou a causa que defendeu e se empenhou por mais da metade de sua vida, que foi o Escotismo, uma prática educativa que disseminou-se mundo afora após o engajamento de Baden-Powell em fundá-lo na Inglaterra, verifica-se que ele enquadra-se dentre os intelectuais "[...] que tiveram importância enquanto viveram". (SIRINELLI, 1996, p. 246). Gentleman porque, segundo John Locke, está fundamentada numa concepção integral que contempla a Educação física, moral e intelectual do indivíduo. Quanto à formação intelectual, pode-se dizer que foi produtiva, se tomarmos como parâmetro a sua produção literária (quantita e qualitativamente). Dentre ela destacase Scouting for Boys, um dos livros mais vendidos no mundo em todo século XX. No tocante à educação moral, os valores que recebeu em família e na escola foram motivadores para que os compartilhasse com os jovens ingleses, inicialmente, e mais tarde, aos jovens de todo o mundo, por meio de seus exemplos e também de seus livros. Quanto à educação física, desenvolveu na infância, na escola, nas aventuras com os irmãos mais velhos, no exército e no Escotismo, onde só a deixou quando não tinha mais forças, o que aconteceu quando estava prestes a completar oitenta anos de vida. Sua trajetória de vida foi ativa do início ao fim e nos fornece elementos diversos e possíveis de serem ainda pesquisados e contribuir com a História da Educação, seja ela inglesa, brasileira ou onde quer que o Escotismo tenha fincado raízes.

\section{Referências}

BOULANGER, Antonio. O Chapelão: Histórias da vida de Baden-Powell.Rio de Janeiro: Letra Capita, 2000. 
CHARTIER, Roger. História Cultural: Entre práticas e representações. - Rio de Janeiro: Bertand Brasil, 1990.

COMENIUS, John. Didática Magna. São Paulo: Martins Fontes, 2002.

LE GOFF, Jacques. "Documento/monumento". In: Enciclopédia Einaudi. Memória História. Porto: Imprensa Nacional/Casa da Moeda. V. 1, 1984.

LOCKE, J. Pensamientos sobre la educación. Madrid: Ediciones Akal, 1986.

NASCIMENTO, Jorge Carvalho. (Org.). A Pedagogia do escotismo: o lord Baden-Powell e as reformas educacionais da primeira metade do século XX. In: Problemas de educação escolar e extra-escolar. - São Cristóvão: Editora UFS, 2005.

PEREIRA, Ana Paula Costa. Educação não-formal tendo como exemplo de modelo pedagógico o método escoteiro. Monografia de conclusão de curso de graduação como Bacharel em Pedagogia. Rio de Janeiro: Univercidade, 2004.

POWELL, Baden Lord. Caminho para o sucesso. $2^{\mathrm{a}}$ ed. Rio de Janeiro: Editora Escoteira. 1984.

ROBLEÑO, Fernando. Alerta aos 100 anos! Disponível em: http://www.revistapremier.com.br/site/Post/Post.aspx?id=884 . Acesso em 20 de abril de 2011.

ROUSSEAU, J. J. Emílio ou Da Educação. São Paulo: Martins Fontes, 2004.

SIRINELLI, Jean François. Os intelectuais. In: RÉMOND, Renê. (Org.) Por uma História Política. Rio de janeiro: Editora UFRJ: Fundação Getúlio Vargas. 1996. P. 231-269.

THOMÉ, Nilson. Movimento Escoteiro: Projeto Educativo Extra-Escolar. Revista HISTEDBR. Campinas, n. 23, p. 171-194, set. 2006.

\section{Notas}

\footnotetext{
${ }^{1}$ Mestrando em Educação pela Universidade Tiradentes. Especialista em Metodologia do ensino pela Universidade Federal de Sergipe. Graduado em Educação Física pela Universidade Tiradentes (UNIT). Membro do Grupo de Pesquisa em História das práticas educacionais - GPHPE.

${ }^{2}$ Doutora em Educação pela Universidade Federal do Rio Grande do Norte (UFRN). Docente do programa de pós-graduação em Educação da Universidade Tiradentes (UNIT). Membro do Grupo de Pesquisa em História das práticas educacionais - GPHPE.

${ }^{3}$ O Reverendo Powell era um homem muito culto e respeitado. Possuía conhecimentos nas áreas de matemática, astronomia, filosofia, medicina e teologia, tocava órgão e pintava, era membro da Geographical Society e da Royal Astronomical Society. (BOULANGER, 2000, p. 15)
} 


\footnotetext{
${ }^{4}$ Bôer é uma palavra holandesa que significa fazendeiro, e era utilizada para designar os descendentes dos holandeses que chegaram à África do Sul em 1652 e dominaram a região até 1797, quando foram forçados a capitular diante do Major-General inglês Craig, que chegou lá com oito navios e quatro mil homens para proteger a colônia contra uma possível invasão francesa. (BOULANGER, 2000, p. 82).
}

${ }^{5}$ A brigada tinha sido fundada em Glasgow em 1883 por um comerciante escocês, William Alexander Smith, um tenente do "1 Lancaster Rifle Volunteers" e dedicado professor dominical. Smith, achando que alguns dos rapazes rebeldes e sujos que freqüentavam a sua escola dominical estavam aquém dos padrões disciplinares, teve a idéia de torná-los soldados mirins. Deu-lhes uniformes e armas de madeira. O resultado foi maravilhoso e transformação das maneiras, moral e disciplina tornou a sua experiência digna de ser seguida. (BOULANGER, 2000, p. 99).

${ }^{6} \mathrm{O}$ termo Brownsea Island ou Ilha de Brownsea é, na realidade, uma redundância, pois o nome Brownsea já carrega em si a palavra ilha nas suas últimas duas letras. "Ea" é uma palavra que em dinamarquês antigo significa ilha. Brownsea é portanto uma contração do Original Bronk's Ea, oriundo de algum antigo invasor ou, de acordo com uma lenda, de um certo Bruno que nos tempos de Eduardo, o Confessor, foi Lorde daquelas terras. Localizada na parte sul da Inglaterra, a ilha de Brownsea possui aproximadamente três quilômetros de extensão e dois de largura. Conta com muitos bosques, alguns deles com clareiras de arbustos. A ilha era grande, com muitos bosques, alguns deles com clareiras de arbustos. Baden-Powell inclusive já conhecia Brownsea, pois havia velejado com seus irmãos do Porto de Poole para algumas de suas praias (até mesmo sua futura esposa, Olave, já havia velejado ao redor da ilha quando criança) (BOULANGER, 2000).

7 “Após o sucesso da experiência em Brownsea B-P encontrou-se numa sinuca de bico. Ele tinha várias tarefas a desenvolver simultaneamente: escrever um livro, organizar um tour de palestras, acertar um acordo com Pearson, planejar um jornal semanal, organizar o esquema dos Boys Scouts e, além disso, conseguir autorização do Exército para tocar tudo isso para frente, pois, naquela época, até mesmo um Tenente-General deveria solicitar autorização oficial antes de publicar qualquer coisa ou aceitar outros encargos". (BOULANGER, 2000, p. 119)

${ }^{8}$ Cf. BOULANGER (2000, p. 190-191).

Recebido em janeiro/2012

Aprovado em abril/2012 